\title{
P 111
}

\section{クリーンルームで作業する労働者のストレス度調査}

\section{○金子みどり、加藤元、渡辺浩、水野恵美}

日本アイ・ビー・エム（株）藤沢事業所健康開発支援センター

【はじめに】

職場巡視においてクリーンルームでの作業が 他の職場に比較してストレスを多く感じると推 測された。そこで、某事業所のクリーンルーム で働く作業者のストレス度を調査し、健康管理 面から支援できるサービスを模索するため調查 を行った。

\section{【調查方法】}

クリーンルームで組み立てライン作業を行う 臨時雇用者81名を対象群とし、クリーンルーム 外の製造現場で作業する臨時雇用者33名をコン トロール群として調査した。調查項目は、属性 および産業ストレスなどの評価に用いられてい る日本版Profile of Mood State (POMS) 調查票から構成された。回答は、過去 1 週間の 気分について 5 段階（全くなかつた:0点〜非常 に多くあった:4点）の自己記入を求めた。採点 は、全 65 項目中ダミーの 7 項目を除く 58 項 目を 6 つの感情尺度に分け、各尺度別に回答点 数を合計、さらに、性別により標準化された 3 段階 (点数が高い程、感情尺度が強い。ただ し、感情尺度「活気」のみ 2 段階で、点数が低い 程感情尺度が強い)に分けた。デー夕分析は、 SAS 社の統計解析用ソフトStatView 5 for WindowsにてMann-Whi tneyのU検定を行った。

\section{【結果】}

1. 回収率・有効回答率 :

[対象群] $90.1 \%$ (73人) - $81.5 \%$ (66人)

[コントロール群］ $100 \%$ (33人)・97.0\%(32人)

2. 属性 : 表 1 に示す。

3 . ストレス度 : 表 2 に示す。

4. デー夕分析：各感情尺度において、対象群 およびコントロール群間に統計学的な有意差は 認められなかった（表 3 参照）。

\section{【考察】}

クリーンルームでの作業は、環境および業務 内容が原因となりストレスをより多く感じると 推測されたが、今回の調查では、両群間で各感 情尺度における統計学的な有意差は認められな かった。

ただし、「怒り一敵意」の感情尺度に関して、 統計学的な有意差は認められなかったものの、 分布からみて対象群がコントロール群に比べ高 い傾向にあった。そのため、さらに詳細な調査 を行い、より快適で働きやすい環境づくりと健 康管理面での支援サービスを検討する必要があ ると思われた。

【参考文献】

横山和仁, 荒記俊一：日本版 P O M S 手引, 金子書房, 2000.
表1. 属性

\begin{tabular}{|c|c|c|c|c|}
\hline \multirow{4}{*}{ 対象群 } & & 人数 $($ 人) & 平均年令 (才) & 勤務期間（月） \\
\hline & & 66 & $27.5 \pm 5.6$ & $12.8 \pm 5.2$ \\
\hline & 男性 & 37 & $27.3 \pm 4.6$ & $13.3 \pm 5.3$ \\
\hline & 女性 & 29 & $27.8 \pm 6.7$ & $12.2 \pm 5.2$ \\
\hline \multirow[t]{3}{*}{ コントロール群 } & & 32 & $25.4 \pm 5.6$ & $8.3 \pm 5.3$ \\
\hline & 男性 & 24 & $24.7 \pm 5.2$ & $7.8 \pm 4.6$ \\
\hline & 女性 & 8 & $27.5 \pm 6.6$ & $10.0 \pm 7.3$ \\
\hline
\end{tabular}

表3.2群間の比較(Mann-WhitneyのU検定)

\begin{tabular}{|c|c|c|c|c|c|c|}
\hline 感情尺度 & 緊張一不安 & 抑うつ一落込み & 怒り一䑤意 & 活筑 & 疲労 & 混乱 \\
\hline $\mathrm{p}$ 值 & 0.248 & 0.310 & 0.154 & 0.644 & 0.654 & 0.763 \\
\hline
\end{tabular}

表2.POMS3段階評価の分布

\begin{tabular}{|c|c|c|c|c|c|c|c|c|c|}
\hline \multirow[t]{2}{*}{ 感情尺度 } & \multicolumn{3}{|c|}{ 緊張－不安 } & \multicolumn{3}{|c|}{ 抑うつー落込み } & \multicolumn{3}{|c|}{ 怒りー敵意 } \\
\hline & 1 & 2 & 3 & 1 & 2 & 3 & 1 & 2 & 3 \\
\hline $\begin{array}{l}\text { 対象群 (66名) } \\
\text { コントロール群 (32名) }\end{array}$ & $\begin{array}{l}74.2(49) \\
84.4(27) \\
\end{array}$ & $\begin{array}{l}18.2(12) \\
12.5(4) \\
\end{array}$ & $\begin{array}{l}7.6(5) \\
3.1(1) \\
\end{array}$ & $\begin{array}{l}65.2(43) \\
78.1(25) \\
\end{array}$ & $\begin{array}{r}27.3(18) \\
9.4(3) \\
\end{array}$ & $\begin{array}{r}7.6(5) \\
12.5(4)\end{array}$ & $\begin{array}{l}60.6(40) \\
75.0(24)\end{array}$ & $\begin{array}{l}27.3(18) \\
18.7(6)\end{array}$ & $\begin{array}{r}12.1(8) \\
6.3(2)\end{array}$ \\
\hline
\end{tabular}

\begin{tabular}{|c|c|c|c|c|c|c|c|c|}
\hline \multirow[t]{2}{*}{ 感情尺度 } & \multicolumn{2}{|c|}{ 活気 } & \multicolumn{3}{|c|}{ 疲労 } & \multicolumn{3}{|c|}{ 混乱 } \\
\hline & 1 & 2 & 1 & 2 & 3 & 1 & 2 & 3 \\
\hline 対象群 (66名) & $42.4(28)$ & $57.6(38)$ & $65.2(43)$ & $28.8(19)$ & $6.1(4)$ & $77.3(51)$ & $18.2(12)$ & $4.6(3)$ \\
\hline コントロール群 (32名) & $37.5(12)$ & $62.5(20)$ & $62.5(20)$ & $25.0(8)$ & $12.5(4)$ & $81.3(26)$ & $9.4(3)$ & $9.4(3)$ \\
\hline
\end{tabular}

